\title{
HOCKEY ATHLETE'S MOOD LEVEL DURING TRAINING IN THE TIME OF COVID-19 PANDEMIC
}

\author{
Yudi Hidayat $^{1}$, Sumbara Hambali ${ }^{2}$ \\ STKIP Pasundan ${ }^{1,2}$ \\ hidayatyudi.zyss69@gmail.com¹,sumbarahambali8@gmail.com²
}

\begin{abstract}
The purpose of this research was to determine how big the level of mood and the factors that affect the mood of athletes during extracurricular hockey training, both independent training and joint training based on each indicator at SMAN 14 Tangerang Regency. This type of research is quantitative descriptive research with survey method. The population and sample in this study were all members of the hockey extracurricular at SMAN 14 Tangerang Regency, totaling 25 people and sampling using total sampling technique. The instrument used was a study a rating scale questionnaire in the form of a checklist. The number of question items in the questionnaire is 21 questions that have been tested for validity and reliability. The questionnaire about mood is divided into several indicators, including fatigue, angry mood, feeling ready, energetic and full of energy, tension, selfassessment, confused mood, depression. Data collection techniques were carried out online using the help of social media whatsapp and google form. Data calculation and analysis in this study through a quantitative approach in the form of percentages. Based on the results of the research, it showed that the mood level of hockey extracurricular members was in the low category, namely the self-assessment indicator $(55,2 \%)$ while for the very low category the indicator of feeling ready (45,5\%), the anger mood indicator $(33,8 \%)$, confused mood indicator $(31,7 \%)$, tension indicator and depression indicator $(21,6 \%)$ and fatigue indicator (17,2\%). Of all these indicators, self-assessment is in the low category and the fatigue indicator is in the very low category.
\end{abstract}

Keywords: Mood, Hockey, Extracurricular, Pandemic Covid-19

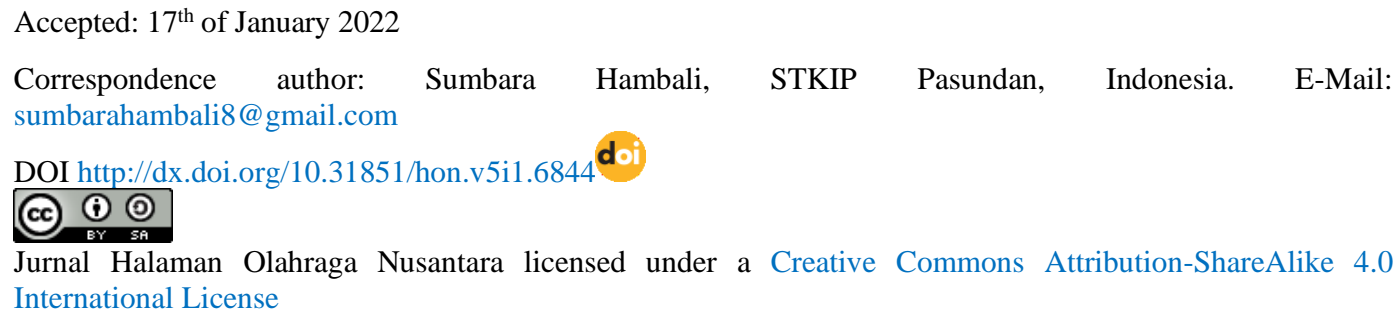

\section{INTRODUCTION}

Hockey is a high intensity sport with fast play, quickly passing the ball, slightly processing the ball, running quickly towards the opponent's goal and running fast to withstand the opponent's attack, and trying to get the ball into the opponent's goal. Players are required to have a good level of physical condition for maximum achievement (Hildan Efendi \& Made Pramono, 2016). Not only 
relying on physical conditions in the game of hockey also requires good psychology.

Hockey is divided into several types, namely: field hockey (outdoor), room hockey (indoor) and ice hockey. Of the three types of hockey, outdoor hockey and indoor hockey are more developed in Indonesia considering the situation and condition of existing facilities and infrastructure (In'am Attaqi et al, 2016).

In student hockey matches there are several notes that are of basic concern, including the quality of individuals who are lacking in mastering basic skills and especially psychological factors where there must be someone who drives, directs, so that the appearance is a combination of various factors, where the psychological factor is very important. play a big role. It can be seen, among others, the strength and weakness of the drive to achieve achievements and win matches. (Hasibuan et al., 2015).

The world is busy discussing a new virus that first appeared at the end of 2019 in Wuhan, China, namely COVID-19 which has really changed the order of life in the world (Puri Wahyu Puspitasari, 2020). Restrictions on educational activities force educational actors (teachers and students) to study and learn from home virtually (online) (Rahman, Prasetyo, \& Mashuri, 2021). Indonesia is no exception, learning in schools has stopped altogether. This is due to the case of the spread of the COVID-19 virus (Hambali et al., 2021). Another impact was felt in the world of sports, all sporting events were postponed or even forced to be cancelled. During this Covid-19 pandemic, virtual or online learning and training is the most appropriate choice. But on the other hand, it can be an alternative medium for the transfer of knowledge or expertise. On the other hand, athletes also experience psychological disorders due to online training (Divina et al., 2020). They are usually more interested in playing electronic games such as online games, gadgets and other electronic games. They feel very comfortable to play the game without feeling boredom and boredom for a long period of time, compared to doing motion activities (Asri \& O., 2021). 
Emotions or feelings of athletes need special attention in sports, because athletes' emotions affect other psychological aspects. Emotional disturbances to athletes will affect the athlete's mental state as a whole, emotional instability or "emotional instability" will result in "psychological instability", and ultimately affect the athlete's achievement (Tirto Apriyanto, 2016).

In addition, the state of the mood is also something that must be considered in achieving maximum exercise results. Mood or mental set is a mental atmosphere related to the emotional response experienced by a person in connection with daily activities which in turn affects the performance of work tasks in SMEP 1998. When training is in progress, the mood is a determinant of the athlete's performance in carrying out any program given by the coach. Mood conditions that affect the performance of work tasks in the SMEP (Monitoring Evaluation and Reporting System) include; fatigue, anger, feeling ready, tension, self-assessment, confusion, depression (Sri Wahyuni Gultom, 2018).

Saturation, boredom in doing exercises every day makes athletes feel stressed, tired which results in a lack of enthusiasm so that motivation and mood in doing exercises will decrease until finally they are reluctant to become an athlete (Wahyudi, 2020).

Based on the description above, the author is interested in conducting a study entitled "Hockey Athlete's Mood Level During Training In The Time Of The Covid-19 Pandemic".

\section{METHOD}

The method used in this research is descriptive quantitative method. The population in this study were all members of the hockey extracurricular at SMAN 14 Tangerang Regency, amounting to 25 people. With the sampling technique using total sampling, the entire population is used as a sample. This means that the sample in this study was 25 members of the hockey extracurricular at SMAN 14 Tangerang Regency. 
The research instrument is using a rating scale questionnaire/questionnaire in the form of a checklist. Data collection techniques were carried out online using the help of social media whatsapp and google form. There are 35 questions related to the psychological mood (mood) that athletes feel during exercise with indicators of fatigue, anger, feeling ready, tension, self-assessment, confusion and depression. The value range of scores 0-7 contained in the questionnaire means that when ticking $(\sqrt{ })$ the number 0 means that psychological symptoms are not felt, and vice versa if the greater the score that is ticked $(\sqrt{ })$ means the higher the perceived psychological symptoms.

From the data obtained as many as 35 items, there are several items that are not valid other 14 questions, while the other 21 questions are said to be valid because they meet the test validity requirements and deserve to be distributed to respondents. The instrument reliability criteria show that the reliability value of 0,945 is said to be very high and feasible to be used in research.

The technique of calculating and analyzing data in this study uses a quantitative approach in the form of percentage analysis, namely by dividing the total score obtained by the total score multiplied by $100 \%$. Category assessment is carried out with conversion criteria, the categories used in the assessment of the average score of respondents' responses, as presented in the following:

Table 1. Rating Category

\begin{tabular}{ccc}
\hline No & Category & Interval \\
\hline 1. & Very High & $78-100 \%$ \\
2. & High & $53-77 \%$ \\
3. & Low & $26-52 \%$ \\
4. & Very Low & $0-25 \%$ \\
\hline
\end{tabular}

\section{RESULT AND DISCUSSION}

After conducting research using the distribution of questionnaires/questionnaires via google form with 21 question items for hockey athletes with a total of 25 respondents. The following are the results of research 
regarding an overview of how much students' mood levels are when facing independent practice during the Covid-19 pandemic.

\section{Results of Athlete Mood Research Based on Mood Condition Category}

Table 2. Frequency Distribution of Respondents Based on Mood Condition

\begin{tabular}{ccc}
\hline Category & $\begin{array}{c}\text { Frequency } \\
\text { Nomber of Respondents }\end{array}$ & Percentage (\%) \\
\hline Very High (78-100) & 0 & 0 \\
High (53-77) & 0 & $0 \%$ \\
Low (26-54) & 2 & $8 \%$ \\
Very Low (0-25) & 23 & $92 \%$ \\
Total & 25 & $100 \%$ \\
\hline
\end{tabular}

Based on Table 2 shows that almost half of the respondents are in the low category.

\section{Score Results for Each Question Indicator}

Table 3. Score Results from Each Question Indicator

\begin{tabular}{cccccccccccccc}
\hline \multicolumn{2}{c}{ Fatigue } & \multicolumn{2}{c}{$\begin{array}{c}\text { Angry } \\
\text { Mood }\end{array}$} & \multicolumn{2}{c}{$\begin{array}{c}\text { Feeling } \\
\text { Ready }\end{array}$} & \multicolumn{2}{c}{ Tension } & \multicolumn{2}{c}{$\begin{array}{c}\text { Self } \\
\text { Assessment }\end{array}$} & \multicolumn{2}{c}{$\begin{array}{c}\text { Confused } \\
\text { Mood }\end{array}$} & Depression \\
\hline No & Score & No & Score & No & Score & No & Score & No & Score & No & Score & No & Score \\
10 & 35 & 1 & 16,6 & 2 & 41,7 & 6 & 22 & 7 & 64,0 & 3 & 20,6 & 4 & 32 \\
14 & 17,7 & 11 & 32 & 5 & 48,6 & 12 & 24 & 13 & 31,4 & 8 & 28,6 & 9 & 13 \\
& & 15 & 22 & 16 & 49 & 17 & 20 & 19 & 73,7 & 20 & 48 & 21 & 21 \\
& & 18 & 33 & & & & & & & & & & 67,1 \\
Total & 52,7 & & 103,6 & & 139,3 & & 66 & & 169,1 & & 97,1 & \\
\hline
\end{tabular}

Based on Table 3 above, it shows that the self-assessment score has the highest score of 169,1 and the fatigue score has the lowest score of 52,7.

\section{Research Results based on Mental State Indicators}

Table 4. Research Results Based on Indicators of Mental State

\begin{tabular}{cccccc}
\hline NO & STATE & FREQUENCY & SHOULD & PERCENTAGE & CATEGORY \\
& & & & & \\
\hline 1 & Fatigue & 30,1 & 175 & 17,2 & Very Low \\
2 & Angry Mood & 59,2 & 175 & 33,8 & Very Low \\
3 & Feeling Ready & 79,6 & 175 & 45,5 & Very Low \\
4 & Tension & 37,7 & 175 & 21,6 & Very Low \\
5 & Self-Assessment & 96,7 & 175 & 55,2 & Low \\
6 & Confused Mood & 55,5 & 175 & 31,7 & Very Low \\
7 & Depression & 37,7 & 175 & 21,6 & Very Low \\
& Total & 396,5 & 1225,0 & & \\
\hline
\end{tabular}


These results indicate that the athlete's mood level during training during the Covid-19 pandemic with 7 indicators that affect the athlete's mood level, namely fatigue, anger, feeling ready, tension, self-assessment, confusion and depression. For more details will be explained as follows:

\section{Fatigue Indicator}

From the data obtained the results of data analysis with a score of $17,2 \%$ which can be categorized as very low because of symptoms of a psychological atmosphere such as muscle aches even though they are resting, feeling helpless and not feeling fit. Fatigue experienced during exercise must be immediately recovered, so that fatigue will not last long. The human body has a maximum capacity limit and requires time to rest, in addition to restoring muscle strength as well as to regenerate muscles that have been damaged during exercise, so that new muscles are formed that have better quality than before (I Made Yoga Parwata, 2015).

\section{Angry Mood Indicator}

Most of the indicators of the mood of anger still feel symptoms of a psychological atmosphere such as feeling disappointed, unable to control emotions, feeling tense, and like to hold back anger with a percentage of $33,8 \%$ with a very low category. Therefore, the coach must provide a fun training program. In addition, an atmosphere of anger also needs to be carried out in training sessions to increase emotion, but it must be suppressed and controlled so that it becomes a positive emotion so that it will become energy that can motivate athletes to increase enthusiasm and high fighting power when doing exercises and competitions. Sri Wahyuni Gultom, 2018).

\section{Feeling Ready Indicator}

Indicators of feeling ready that can be known some still feel symptoms of a psychological atmosphere such as excess energy, the task feels light, and feels steady full of energy, has a percentage of $45,5 \%$ with a very low category. Part of the psychological aspect that plays an important role in the formation of athlete 


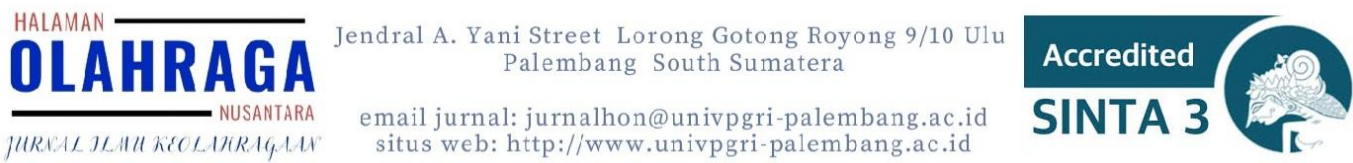

performance is self-confidence. Lack of self-confidence will affect the confidence and fighting power of the athlete (Setyawati, 2014).

\section{Tension Indicator}

From the data obtained, the results of data analysis with a score of 21,6\% are categorized as very low. From these indicators, those who experience symptoms of a psychological atmosphere such as feeling overwhelmed with anxiety, feeling restless, and feeling anxious. This means that the hockey athletes of SMAN 14 Tangerang Regency do not have tension or anxiety in doing exercises. But before the match, tension is needed within certain limits, so that the athlete is ready to face and carry out the task carefully and well. Without tension before the match, it can be said that the athlete is still sleeping psychologically, so he will not be able to do much in his duties (Effendi, 2016).

\section{Self-Assessment Indicator}

Indicators of the state of self-assessment that can be seen by athletes, some still feel symptoms of a psychological atmosphere such as feeling able to carry out their duties, feeling not doing much, and feeling able to carry out their duties, so they have a percentage of $55,2 \%$ in the low category. This means that hockey athletes at SMAN 14 Tangerang Regency have confidence in doing their job well. When one feels confident, one's mind is free to focus on the task at hand. If the athlete lacks self-confidence, they tend to worry about how well the athlete is doing or think about how well others are doing (Mirhan, 2016).

\section{Confused Mood Indicator}

The indicator of the state of confusion that can be seen by athletes, some still feel symptoms of psychological conditions such as feeling stuck, unable to concentrate, going awry, and forgetting about failure, so they have a percentage of $31,7 \%$ in the very low category. This means that the hockey athletes of SMAN 14 Tangerang Regency feel able to control the confused atmosphere and can concentrate well. Ways to increase concentration include looking and thinking on a particular object, taking deep breaths, good body language, and doing rituals (habits) (Nusufi, 2016). 


\section{Depression Indicator}

Some of the indicators of depression that can be seen by athletes still feel symptoms of a psychological atmosphere such as being alone, feeling isolated in a group, and the coach or friend feels hostile, so they have a percentage of $21,6 \%$ with a very low category. This means that the level of depression is very low for hockey athletes at SMAN 14 Tangerang Regency, this is because the training model provided by the trainer is very varied and always creates an encouraging atmosphere but remains on the track of the training program. Regular physical exercise can improve the quantity and quality of sleep needs so that it affects energy and better body activity (Kusumowardani, 2011).

\section{Percentage and Frequency of Mood Level}
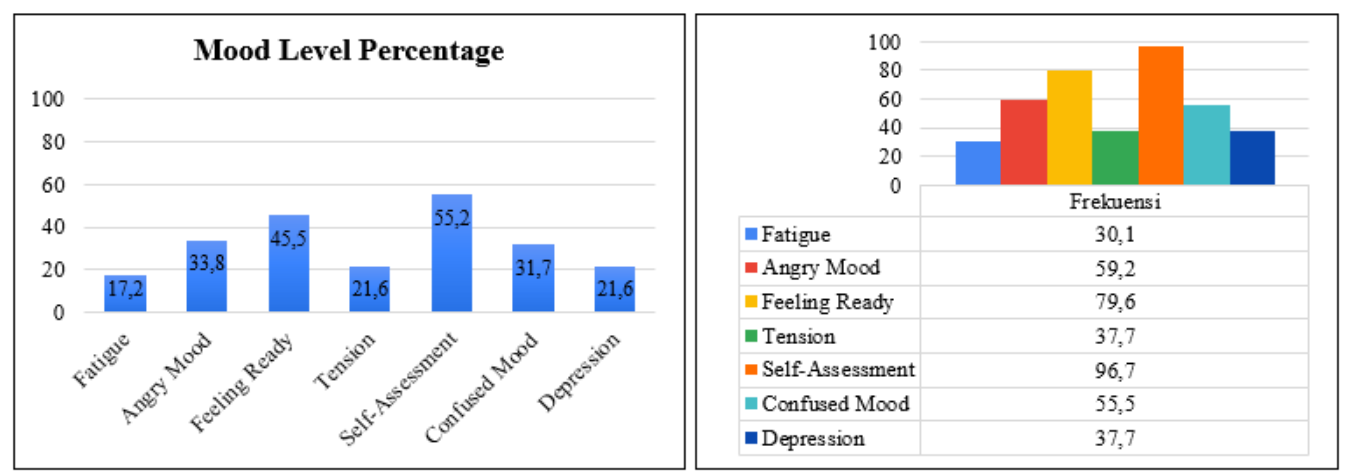

Figure 1. Percentage and Frequency of mood level

The graphic image above shows that the fatigue indicator gets a frequency of answers of 30,1 or $17,2 \%$ in the very low category, the angry mood indicator gets a frequency of answers 59,2 or $33,8 \%$ in the very low category, the feeling indicator is ready to get an answer frequency of 79,6 or $45,5 \%$ in the very low category, the tension indicator gets the frequency of answers 37,7 or $21,6 \%$ in the very low category, the self-assessment indicator gets the answer frequency 96,7 or $55,2 \%$ in the low category, the atmosphere indicator confused to get an answer frequency of 55,5 or $31,7 \%$ in the very low category and depression indicators get an answer frequency of 37,7 or $21,6 \%$ in the very low category. 


\section{HALAMAN Tendral A. Yani Street Lorong Gotong Royong $9 / 10$ Ulu OLAHRAGA

\section{CONCLUSION}

Based on the results of research and discussion regarding the mood level of hockey athletes during the Covid-19 pandemic, it was shown that the mood of hockey athletes at SMAN 14 Tangerang Regency is very low with a percentage of $33,04 \%$. This means that this research is limited to knowing the mood of the athlete in doing the exercise and how big the mood of the hockey athlete at SMAN 14 Tangerang Regency after doing the exercise. In addition, the mood state of hockey athletes at SMAN 14 Tangerang Regency with indicators of fatigue, feeling ready, tension, depression, anger, and confusion in the very low category, while the self-assessment indicator is in the low category. This means that even though the hockey athletes practice during the pandemic and do not have enough test matches or the competition calendar is not clear, they can still cope well with their psychological state with regular training capital during the Covid19 pandemic.

\section{REFERENCES}

Divina, Anatasya, Marselius Sampe Tondok, Aninditya Radini, dan Fransiska Julia. 2020. "Pendampingan Komunitas Atlet Bola Voli Melalui Pelatihan Virtual Goal Setting untuk Meningkatkan Motivasi Berprestasi pada Masa Pandemi Covid-19." 04(02): 476-92.

Effendi, Hastria. 2016. "Peranan psikologi olahraga dalam meningkatkan prestasi atlet." Nusantara (Jurnal Ilmu Pengetahuan Sosial) 1: 23-30.

Hambali, S., Akbaruddin, A., Bustomi, D., Rifai, A., Iskandar, T., Ridlo, A. F., ... Tyas, R. A. (2021). The effectiveness learning of physical education on pandemic covid-19. International Journal of Human Movement and Sports Sciences, 9(2), 219-223. https://doi.org/10.13189/saj.2021.090208

Hasibuan, Bangun Setia et al. 2015. "Hubungan Antara Kecemasan Dan Agresivitas Dengan Prestasi Olahraga Beladiri Tarung Derajat Pada Atlet Petarung Putra." Jurnal fisoterapi 15(2).

Hildan Efendi \& made Pramono. 2016. "Kajian Kecemasan Atlet Hockey Putra Kabupaten Gresik Sebelum Bertanding di PORPROV Jawa Timur Tahun 2015." Jurnal Kesehatan Olahraga 6: 5-10.

I Made Yoga Parwata. 2015. "Kelelahan Dan Recovery Dalam Olahraga." ISSN : 2337 - 9561 Jurnal Pendidikan Kesehatan Rekreasi Volume 1: Hal. 2 - 13 151(1): 10-17. 
In'am Attaqi et all. 2016. "Pengambangan Model Alat Stick Hockey Untuk Latihan Pemain Pemula Hockey". Journal of Physical Education , Sport , Health and Recreations. 5(3).

Kusumowardani. 2011. "Model Latihan Fisik dalam Menurunkan tingkat Depresi pada Pasien." Jurnal Terpadu Ilmu Kesehatan 3: 203-6. http://jurnal.poltekkes-solo.ac.id/index.php/Int/article/view/49.

Mirhan, Jeane Betty Kurnia Jusuf. 2016. "Hubungan Antara Percaya Diri Dan Kerja Keras Dalam Olahraga Dan Keterampilan Hidup" Jurnal Olahraga Prestasi 12(1): 86-96.

Nusufi, Maemun. 2016. "Melatih Konsentrasi Dalam Olahraga." Jurnal Ilmu Keolahragaan15(2):54-61.

https://jurnal.unimed.ac.id/2012/index.php/JIK/article/view/6139/5439.

Puri Wahyu Puspitasari. 2020. "Gizi Pada Atlet Puslatkot Kediri Cabang Olahraga Terukur Unggulan Menuju Porprov Vii Tahun 2021 Dalam Masa Pandemi Covid-19."

Asri, N., \& O., E. S. L. (2021). Aktivitas Olahraga Di Masa Pandemi Covid-19 Terhadap Tingkat Stres Mahasiswa Pendidikan Olahraga Universitas Islam Kalimantan Muhammad Arsyad Al Banjari Banjarmasin. Halaman Olahraga Nusantara (HON), 4(1), 53-65. https://doi.org/10.31851/hon.v4i1.5213

Rahman, T., Prasetyo, D. A., \& Mashuri, H. (2021). The Impact Of Online Learning During The Covid-19 Pandemic On Physical Education Teachers.

Halaman Olahraga Nusantara (HON), 4(2), 294-304. https://doi.org/http://dx.doi.org/10.31851/hon.v4i25638

Setyawati, Heny. 2014. "Strategi Intervensi Peningkatan Rasa Percaya Diri Melalui Imagery Training Pada Atlet Wushu Jawa Tengah". Journal of Physical Education, Health and Sport 48(1): 48-59. http://journal.unnes.ac.id/nju/index.php/jpehs

Sri Wahyuni Gultom. 2018. "Profil Kondisi Fisik Dan Mood Atlet Putra Unimed Hockey Club Tahun 2012.” 1(2): 53-62. https://ejurnalunsam.id/index.php/jors.

Tirto Apriyanto. 2016. "No Title." Analisis Skala MOOD Atlet Bola Voli Putri Pelatda DKI JAKARTA: 275-84. 